\title{
Integrin Alpha-X
}

National Cancer Institute

\section{Source}

National Cancer Institute. Integrin Alpha-X. NCI Thesaurus. Code C16789.

Integ rin alpha-X (1163 aa, $\sim 128 \mathrm{kDa}$ ) is encoded by the human IT GAX gene. This protein is involved in cell-matrix interactions and integrin signaling. 